San Antonio Review • San Antonio Review (No. 5, Summer 2021)

\title{
I Do Not Say
}

\author{
H. Leivick, Ash Lange
}

Published on: Apr 11, 2021

DOI: $10.21428 / 9 b 43 c d 98.4 d 41482 c$

License: Creative Commons Attribution 4.0 International License (CC-BY 4.0). 
I do not say that my life is a defeat;

I say only that when stormwind tears down

The strongest apple tree, its apples

The guardian gathers in his basket.

I do not say that my life is a mistake;

I say only that a walker on a rope

Over deep abysses goes and sings

As if under his feet there was a bridge.

I do not say that my life is a dream;

I say only that a rider on a horse

Rides through the whole world and comes riding

Back, where stands his cradle upon the earth.

I do not say that my life is passed;

I say only that the sun sinks in the sea -

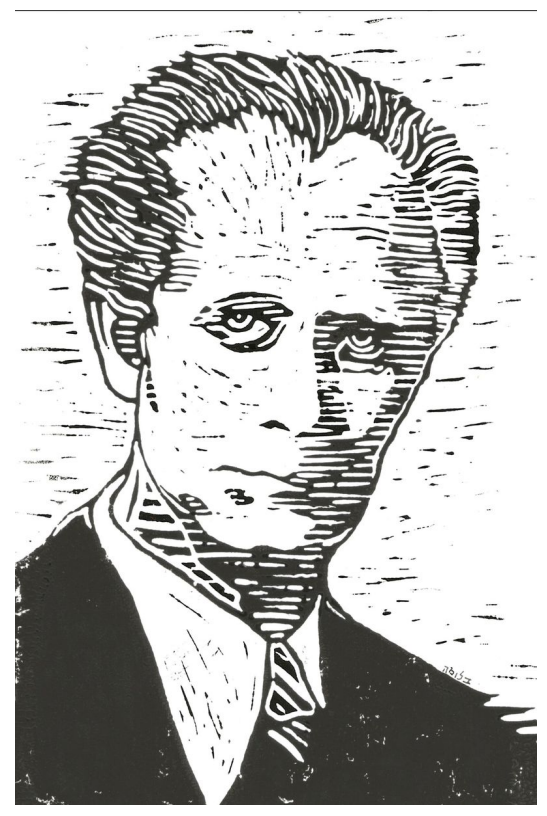

H. Leivick, Lino cut by A.S. Robertson

A circle of sunset fire,

That kindles still in the west a flame.

From Lider Tsum Eybikn (Songs to Eternity), 1959

A note from the translator: During Scotland's lockdown, I had the good fortune of stumbling upon the work of a writer whose name had never turned up in all my many years of Hebrew/Jewish education: H. Leivick. Perhaps he was too Socialist. Or too Yiddish. Too, somehow, American. Maybe all three. But, somehow, in 2020, I held in my hands the abridged version of one of Leivick's epic poems - "The Wolf" - and knew I wanted more.

Barring a few poems in anthologies, I found that outside of The Golem, there wasn't very much of Leivick's work readily available in English. $\underline{1}$ And so, I began down a road I didn't expect to travel: learning a whole language. 


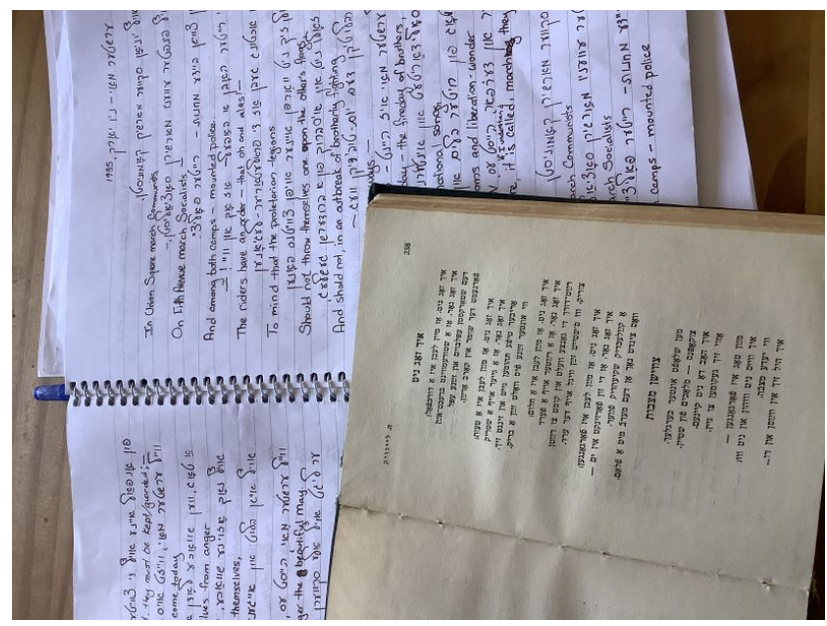

The printed text is of 'I Do Not Say,' the handwritten one for another poem, 'First of May - New York, 1935.
There is, of course, a problem inherent in my working process. Several, in fact. I am not a native speaker, nor have I had any formal training: not in translation nor in Yiddish. And throwing myself on the works of one of the most renowned Yiddish poets and claiming a translation is bad enough without stopping to consider the ramifications of the act itself. What, in fact, does it mean to take the Yiddish of Leivick for whom the language was inextricably tied to personal, spiritual, national and political identity - and to, in the other sense of a "translation," transform it

utterly? I don't have an adequate answer for that yet.

This is a work in progress in which I have kept as closely as possible to word choice and meaning, excluding a slight obscurity in English in the last line of the first stanza - which I have attempted to clarify. The original line reads, roughly, that "the guard occupies/concerns himself with the basket" and while the meaning of "gathering" is, thus, implied, I have chosen to underline the action of gathering in light of Leivick's deployment of the apple tree as a symbol in other works. In 'The Apple Tree Recounts' (Lider Fun Gan Eyden, 1937) the speaker is an apple tree that has been robbed of its ability to produce apples - the poem written during a period when Leivick was seriously ill with tuberculosis. His penultimate collection was titled A Blat Oyf An Eplboym (1954) and Leivick says of this title

I call this book 'A Leaf on an Apple Tree' [....] Of all of the trees around my childhood-home, the dearest to me was an old apple tree. It comes to me, in my dreams of late, dressed in apples and in leaves, and I hear it as it sings to each of its apples, each of its leaves: 'Have no fear that you must fall at the end of the summer. Next year you will return.'

It's good to hear such a thing - even if in a dream.

All of which, I felt, supported making the act of gathering the apples clearer. $\underline{2}$ 
I have not preserved the meter or rhyme-scheme; Leivick's original is a meticulous $a b c b$. However, I feel, at least in this initial stage, it would take something away from the power of his images to try to force it into the same shape. $\underline{3}$

Please permit me to end on a small call for feedback. Comments and questions are not only welcome, they are encouraged! Do get in touch, even if it's only to have a schmooze (a good Yiddish word) about H. Leivick, translation, Duolingo Yiddish, Scottish weather or why it's so hard to find good a pastrami on rye these days.

H. Leivick is the pen name of poet and dramatist Leivick Halpern (1888-1962). Born in Ihumen, Russia (now Chervyen, Belarus), he was arrested in 1906 as a member of the Bund and sentenced to labor and exile in Siberia for possession of illegal literature. In 1913, he escaped to America. Leivick is perhaps best known in English for his play The Golem.

Ash Lange is a member of the San Antonio Review editorial collective and amateur Yiddishist living outside Glasgow, Scotland.

\section{Footnotes}

1. I do not, of course, ignore the wonderful translations by Cynthia Ozick, those anthologised in The Norton Anthology of Jewish American Literature (1974) or those in the landmark, bilingual survey of Leivick and his contemporaries, American Yiddish Poetry (1986) by Benjamin and Barbara Harshav. Leivick's corpus is of such size, though, that each of these can only represent a cross-section of his output. $\triangleq$

2. I owe a debt of gratitude to the wonderful people I have met in the wider Yiddish community, who have provided me with invaluable help and encouragement including on this poem. $ヒ$

3. Harold Bloom, in his review of American Yiddish Poetry for the New York Times, remarked that he wished the Harshavs "had enhanced the already great scholarly value of their collection by providing plain prose translations of the poems" and at this juncture, such fidelity to the word is my main intention. $\_$ 